https://doi.org/10.31713/m1122

\title{
CLASSIFICATION THE SALT STOCK AREAS (SAKHALIN FIELD) WITH THE DETECTION OF HYDROCARBON POTENTIAL FOR OPTIMIZATION OF EXPLORATION WORK AND DRILLING FOR OIL AND GAS
}

\author{
Vynnykov Yu.L. \\ The National University "Yuri Kondratyuk Poltava Polytechnic", \\ professor, $\mathrm{ScD}$, professor at the department of drilling and geology, \\ Ukraine \\ Petrash O.V.
}

The National University "Yuri Kondratyuk Poltava Polytechnic", $\mathrm{PhD}$, associate professor at the department of oil and gas engineering and technologies

\section{Vovk M.O.}

The National University "Yuri Kondratyuk Poltava Polytechnic", senior lecturer at the department of drilling and geology, Ukraine

\section{Volchenkova A.V.}

The National University "Yuri Kondratyuk Poltava Polytechnic", senior lecturer at the department of drilling and geology, Ukraine

\section{Novozhenina A.R.}

The National University "Yuri Kondratyuk Poltava Polytechnic", student, Ukraine

\footnotetext{
Abstract

Classification of stock areas is proposed and described based on the features of the internal and external structure of geologic bodies, occurrence mode, height, and reservoir properties (RP). The RP analysis of prospective and discovered reservoir types within traps sealed by salt stocks is carried out. Potential oil and gas areas within the Sakhalin field salt stock have been identified.

\section{Introduction}

Exploration of hydrocarbons depends on a large number of studies and analyses, drilling of wells for different purposes and depths, the correct interpretation of the obtained geological, lithological, geophysical information. From exploration to production (operation) of oil and gas often takes a lot of time and money, but it is much more
} 
profitable than the cost of buying and transporting gas to Ukraine. It is necessary to continue work on expanding our own resources portfolio through the development of new fields because it requires four times less investment.

Modern exploration of oil and gas fields takes into account the principles of optimization and economical use of hydrocarbon and financial resources, drilling resources for exploration and exploitation.

Among the main principles, in addition to the principle of the least time and cost in an energy-saving fashion, it is important to select the minimum number of surveys and wells that will rationally and evenly study each individual formation or field.

To select the best methods for hydrocarbons exploration, it is necessary to assess in detail the prospects of geological bodies. Reservoir rocks discovered by drilling and geological research have uneven properties and characteristics within each geological section. This is often due to the facies environment (primary), but active tectonic (lowering or raising the area, halokinesis, magmatism) environment leads to secondary changes in the strata.

\section{Formation of reservoir rocks and hydrocarbon traps}

The process of formation of rocks, which is a reservoir of oil and gas, begins on the Earth's surface with the formation of terrigenous or carbonate sediment enriched in organic matter. Over millions of years, the thickness of loose sediment turns into a dense rock, which changes with depth its shape, texture, structure, composition, often metamorphosed. This rock can be a source rock [8] or a reservoir rock. If there are certain features (porosity, permeability, mineralogical and particle size distribution, etc.), the rock may be included in the list of objects for the selection of rational methods of exploration and drilling. But, as practice shows, this geological body is not always a formation, and not always the found formation contains enough resources and opportunities for their extraction.

To form a trap, it is necessary: the presence of the source rock, reservoir rock, seal rock, and structural factor that will keep hydrocarbons from migrating.

Porosity (pore volume) and permeability (the ability of the rock to pass liquid) are important factors in the migration and accumulation of oil and gas. Most traditional accumulations of oil and gas are 
found in debris (sandstones and siltstones). Next in number are carbonate reservoirs (limestones, dolomites). Accumulations of some types of unconventional hydrocarbons are extracted from shales, igneous and metamorphic rocks, due to the porosity resulting from destruction.

The porosity in reservoir rocks usually ranges from 5 to 30 percent, but all available pore space is not occupied by oil or gas, there is always a certain amount of residual formation water [12].

\section{Analysis of the geological structure of the oil and gas region with the manifestation of salt tectogenesis}

On the territory of Ukraine, there are 3 oil and gas regions, one of which is the Dnieper-Donetsk basin (DDB).

The Dnieper-Donetsk depression is located in the southwestern part of the Eastern European platform. It is bounded by the Ukrainian Shield (US) and the Voronezh Massif, and has an Archean-Early Proterozoic foundation.

The Dnieper-Donetsk depression is a typical graben with a complex geological structure. The formation of the depression is associated with the processes of rifting (Late Devonian) and tectonic movements (Paleogene). Accordingly, the main coverages in the structure of the depression are the lower coverage - Upper Devonian and upper - Upper Paleozoic-Cenozoic.

The rift contains a thick layer of sedimentary rocks, among which the special by its composition and mode of occurrence are Devonian salt rocks, with which oil and gas reservoirs are associated.

According to the stage of rift formation and the composition of rocks, the Devonian structural coverage is divided into the following complexes: subsalt, lower saline, intersalt, upper saline, and supersalt. Further, with angular and stratigraphic inconsistencies in the Devonian and partly Precambrian formations lie three divisions of the coal system. Within the adjacent parts and marginal zones of the DDB, the Lower Permian ones lie inconsistently, and the Meso- and Cenozoic formations on top of them with the same discrepancy.

Salt tectonics (halokinesis) - movement vertically in the direction of the day surface relative to the light plastics of rock salt. It is believed that the main driving mechanism of this process is the dense inversion at the salt boundary and its overlap. In addition, it is assumed that a certain role in the implementation of this process was 
played by the erosion of the coverage, the weakening of the supersalt complex by faults and uneven load distribution [4].

Salt structures are the result of the pressure of a thick stratum of rocks, which have a higher density and zones of compaction, through which the salt moves towards the day surface.

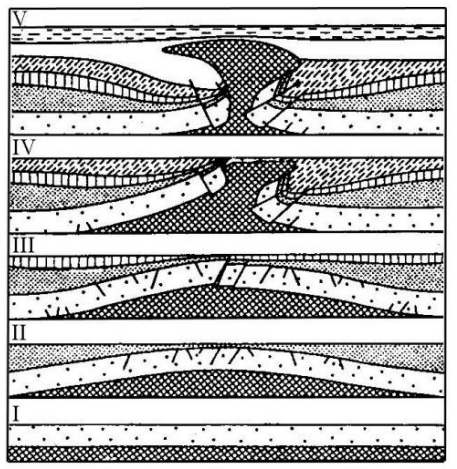

Fig. 1. (Lukiienko O.I.) Schematic representation of the gradual growth and transformation of the diaper body of the shoptein salt in northern Germany (by F.Trusgame, 1960). Roman numerals indicate the phasing of this process, which is expressed in the gradual capture of the horizons of the overlying rocks and the deformation of these horizons (the formation of diapir folds, the development of cracks, etc.)

Saline tectogenesis has been studied at DDB for a long time, not only as a phenomenon but also as one of the factors in the formation of hydrocarbon traps. A significant amount of hydrocarbon reserves at DDB was discovered near the stocks at the Novoukrainske, Chutivske, ZakhidnoKhrestyschenske, Chervonoyarskoe, Vesnyanske, etc. fields.

Salt structures that have the same rheology differ in structure, history of formation, and genesis. In addition, they are still considered "alive", ie those that continue to grow, move and change in space. In such conditions, the lithological-stratigraphic correlation becomes very complicated and the reliability of geophysical surveys decreases.

So, for example, MV Lubkov [5] in 2011 conducted modeling of the salt structures movement within the DDB. The results indicate the inconsistency of these structures in their location and as a result of the existence of modern influence on the adjacent layers of rocks and oil and gas deposits. 
Salt structures within the DDB (according to Lubkov) are divided into three genetic groups.

I - groups are characterized by the fact that all the time over the salt complex of sedimentary rocks, regardless of the level of Devonian salt, forms around the salt core of the dome or anticline. They are formed due to the complication of salt tectonics of the main genetic types of unsalted structures: near-fault, top-fault, stamped, and gutter structures. The cores of group I structures have the shape of a salt cushion or massif.

II - the group of salt structures does not have dome-shaped elevations around the salt core in the lower part's top salt thickness. They have the shape of salt shafts.

Salt structures of group III also have the shape of stocks, are placed between large salt structures of group I or on their periclines, separated by compensating troughs; formation is also linked to regional tensions.

\section{Formation of salt structures and zonation of adjacent zones}

The formation of salt structures is a long process, consisting of two main stages: the formation of thick salt strata and the movement of salt through faults; breaking of salt in unstable areas of overlying rocks. Faults are broken into separate blocks the entire adjacent area.

Vertical movement of salt links took place within the DDB during rifting (Late Jurassic), during the period of intensive stretching, subsidence, backfilling by the overlying rocks with the formation of a thick caprock. This process affected the growth of salt cushions, followed by intense salt removal and, finally, the beginning of the significant vertical movement (late Cretaceous), when the sedimentary load on the salt contributed to its differential movement and rapid rise. Therefore, salt tectonics in the basin is accompanied by prolonged deformation from $\mathrm{J}$ to $\mathrm{Q}$ period.

As salt changes its location and shape, it also changes the shape and location of rocks it breaks through, which in turn affects "neighboring" or higher buried sediments. All rocks involved in the process are subjected to stresses that gradually transfer to each other. The intensity of stress, direction, and form of change of rocks depends on their power, composition, and physicochemical properties. 
The strata of halokinesis rocks are divided into several zones separated by faults and zones of rock disintegration - the body of the salt stock, the adjacent area of intensive change and destruction of rocks, and the area of strata that have not changed their position and properties after breaking the salt stock.

Exploration work in stock adjacent areas is not effective enough, because often the resolution of most methods (seismic, gravimetric, and others) does not allow to accurately trace the boundary between the rock and stock and choose the location for drilling.

In the process of raising the salt massif and its movement along the faults, the rocks through which it passes are destroyed and often bent, forming small in size, but multi-level anticline structures.

Salt stocks destroy the primary form of rocks, creating new forms of geological bodies that meet all the criteria of hydrocarbon structure - traps. The stock adjacent areas have a significant level of fractures of rocks, and some blocks of rocks are raised by tectonic faults.

The adjacent areas are not stable, because the process of halokinesis, like most tectonic processes, is repetitive and can resume its activity in the long-formed salt domes (and other forms of saltinternal and external factors provide (may provide) migration of fluids, not least oil and gas. Among the internal factors can be identified physicochemical properties of the environment, and external include the mass of fluids and their place of greatest concentration, as well as horizontal or vertical stress.

Stress zones or tectonic active zones are found by geophysics as separate anomalies. These anomalies then become areas of compaction, thinning, or displacement of rocks near the stock. Salt stock tectonics affects the surrounding formations with varying intensities. The area of direct contact with the salt stock is the most changed, the area of tectonic faults and blocks, there are minor changes in the structure and content of rocks, the area of monoclinic strata - is part of the strata least susceptible to tectonics and changes.

The leading role of neotectonic and modern movements that determine the conditions of migration and accumulation of oil and gas is recognized by many researchers $[1,5,11]$ and is reflected in the following:

1) areas of oil and gas accumulation are genetically related to deep faults that are currently developing and are manifested in modern movements of the earth's surface; 
2) oil and gas deposits are formed in the zones of unloading of fluid systems on the way of their migration through the zones of increased fracture, where the processes of formation of secondary reservoirs take place;

3) location of oil and gas structures correlates with places of activation of tectonic processes and manifests itself in the form of relatively more intense modern vertical movements of the earth's surface and variability over time of geophysical and geochemical fields;

4) formation of oil and gas fields continues at the present stage of geological development, which makes it appropriate to use neotectonic oil and gas criteria at the exploration stage.

\section{Analysis of reservoir rocks in the stock adjacent areas of the Sakhalin deposit}

The field is located in the northern stock adjacent part of the DnieperDonetsk basin and is confined to the strip of the north-western siege of the Vysokopolsky protrusion of the foundation. (fig. 2).

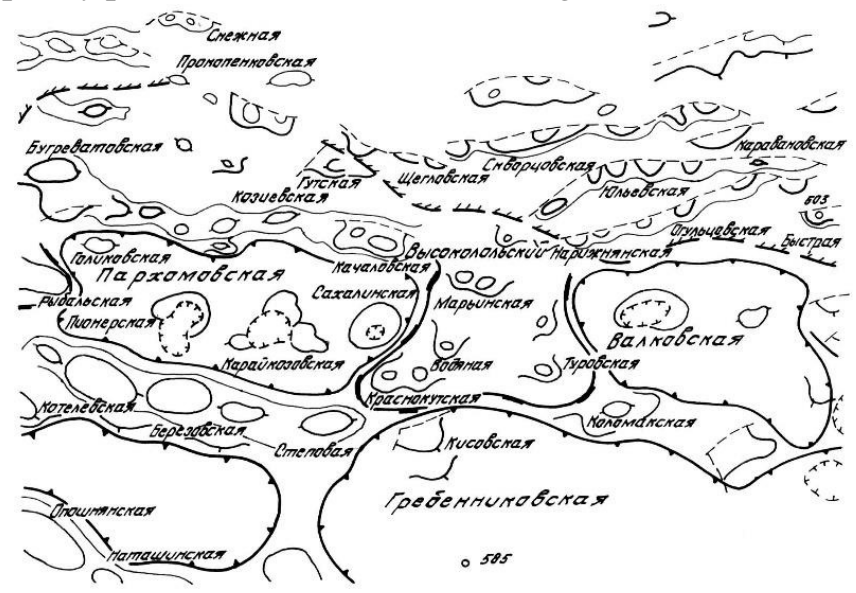

Scale 1:500000

Fig. 2. Tectonic map of the central part and east of DDB (fragment) [7]

According to the existing zoning scheme developed by MP Zyuzkevych on the predominant development of structural forms, Sakhalin field belongs to the Komyshnyansko-Kolomatsky zone of anticline uplifts [3], due tothe combined manifestation of halokinesis and block tectonics. 
The most complex geological structure is observed on the Lower Viseu-Tournai structural subfloor. There is a sharp fluctuation of thicknesses from 0 to $134 \mathrm{~m}$ in the most elevated areas and up to 193 $\mathrm{m}$ - in the submerged ones.

Along with the sedimentary super salt complex, within this part of the depression, a whole group of structures can be traced, which have a certain orientation and form separate long structural-tectonic lines, large shafts, and their deflections.

The Sakhalin uplift has a fairly clear planar position and forms a chain of annular anticlinal forms, which can be traced in the coal complex (Fig. 3).

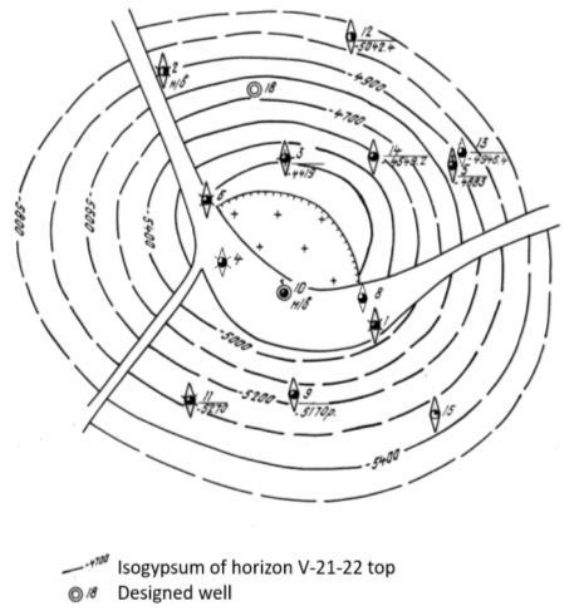

Fig. 3 Lifting structure and layout of designed wells 1,2,4,5,6,8,9,10,11,12,13,14,15 on the top of the horizon V-21-22 Sakhalin field (Solodkyi, Koliada 2009)

According to its genetic characteristics, the Sakhalin uplift (Bilyk OD, Vitenko VO, Ivanyuta MM) belongs to the type of anticlineintermittent-sedimentation salt dome class, cryptodiapir subclass, tectonically disturbed species.

Trace of the main dislocation has amplitudes of 50-800 $\mathrm{m}$ and angles of inclination of the displacement plane of rocks from varying from $30^{\circ}$ to $50^{\circ}$ up the section.

Wrench dislocations complicating the central part of the structure with amplitudes of displacement of rock strata from 20 to $100 \mathrm{~m}$, 
have a multidirectional slope, which gives it a horst and graben stepblock shape.

In general, the Sakhalin uplift on the Upper Serpukhov and Bashkir geological surface of oil and gas has a less pronounced anticlinal dome shape compared to the Upper Viseu structural plan, due to lower intensity of halokinesis. Due to this, the angles of inclination of the rocks decreased, which lie within: the northern wing $20-24^{\circ}$ and the south wing $8-10^{\circ}$, the eastern periclinal $6-7^{\circ}$ and the western $18-20^{\circ}$.

Such diverse dynamics of the manifestation of uplift in different periods of sedimentation led to the creation of three geological structural and tectonic subfloors [8].

- Visean - Lower Serpukhovsky, broken by Devonian salt and divided by the main downthrows into three stepped-submerged parts: northern, southern, and western;

- Upper Serpukhov-Lower Bashkir, formed over the Lower Serpukhov-Visei diapir structural form;

- Upper Bashkir-Moscow-Kasimov hemibrachianticlinal-horstgraben-terraced-monoclinic slope developed over the apical part of the deep diapir fold.

All three geological floors have their own structural differences, and they differ from each other in complexity and severity of structural form, its size, the degree of dismemberment of downthrow dislocations, and oil and gas saturation.

According to the results of our analysis, the differences between the floors are manifested in the values of porosity, permeability, and thickness of the layers.

Common to all structural geological floors is the heredity of the general shape and the coincidence of the apical part of the rise.

Wells 15,16,21, and 12 reveal carbon deposits, which are almost intact, in places raised layers, which are remote from the salt stock (fig. 2). In all strata discovered by wells of Viseu, Serpukhov, Moscow, and Upper Coal ages, the porosity does not exceed $8.5-2.5 \%$ (in one case $13 \%$ ).

In the blocks located close to and above the salt stock, wells $4,5,7,8,9$, and 13 have porosity values greater than 10 to $15.75 \%$. Layers of rocks that are exposed to these wells have an unsustainable 
capacity, often wedged, especially closer to the faults and above the stock.

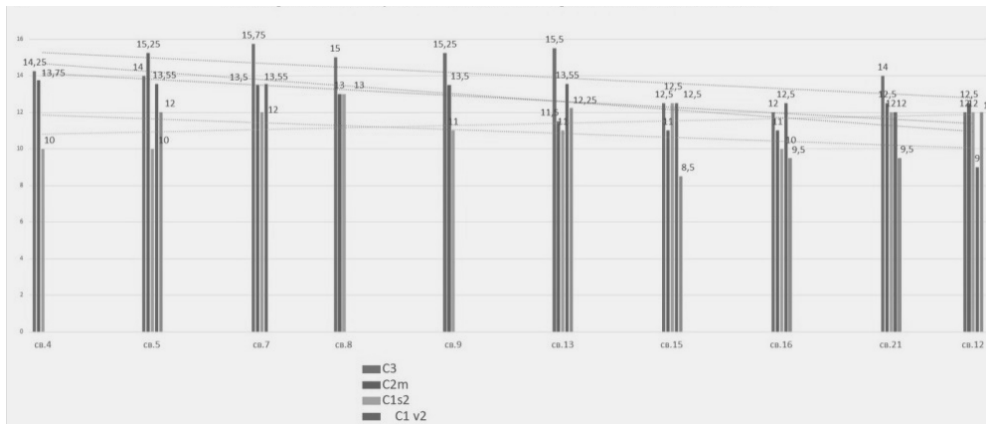

Fig. 4. Graph of changes in the porosity of coal deposits within the tributary zone of the Sakhalin deposit (Vovk M.O.)

Deposits within the section are reservoir, vaulted, dislocated, limited by downthrow dislocations, and salt stock. The total amount of sandiness of the section of the formation in the field is $62,4-82,5 \%$.

The well taking the apical position (№ 8) at the depth of $4581 \mathrm{~m}$ under the upper part of the Lower Serpukhov deposits penetrated the stock Devonian salt, and in well № 1, which is $50 \mathrm{~m}$ deeper, the stock salt was not discovered. This once again confirms the high degree of complexity of the geological composition of the structure, and especially its roof part, on the lower coal complex. Well №8 discovered the production gas potential of the Upper Serpukhov and oil saturation of the Moscow deposits (layers C-4b2, C-5b and M-2a).

The terrigenous material of pay zones is well sorted, which provides it with high filtration-capacity properties: gas permeability is

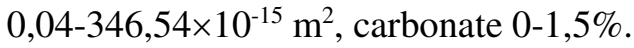

The well № 15, remote from the salt structure, with a design depth of 5,800 m, gave a weak gas manifestation in the Viseu deposits (B-16). The obtained geological information indicates a decrease in the reservoir properties of the formation rocks of the upper Viseu section.

Reservoir properties of core samples studied in the laboratory are: open porosity varies within 7,2-14,5\%, gas permeability - 0,21$94,21 \times 10^{-15} \mathrm{~m}^{2}$, carbonate $-0-21,9 \%$. 
Thicknesses of sandy rocks are quite variable, varying from $0.6 \mathrm{~m}$ (well № 12), 2.2 m (well № 16), 1.4-2.0 m (wells №№ 5, 13) to 11, 8 $\mathrm{m}$ (well 21) on the submerged parts of the field. Much higher effective thicknesses from $3.8 \mathrm{~m}$ to $16.2 \mathrm{~m}$ are confined to the central roof and the northernmost elevated part.

Thus, within the field, there may be identified areas of influence of halokinesis and potential oil and gas saturation.

After analyzing the results of exploration work within the salt stock of the Sakhalin deposit [7], we identified the main structures and elements that exist in the stock zone, the zonation of forms and the properties of rocks.

In our opinion, the rock zone associated with the salt stock has the following characteristics:

1. Tributary blocks have angles of occurrence of rock layers > $30^{\circ}$;

2. The presence of tectonic breccia. It is a mixture of rock salt and ruined rock in the stock zone;

3. The presence of a system of downthrows, or rather the presence of SSS (salt-shear structures) - zones of ancient deep faults, which are channels of fluid heat and mass transfer and are the causes of changes in the properties and types of reservoirs [1];

4. Rocks of tributary zones are weakly cemented, not compacted;

5. There is an increase in the thickness of the stratigraphic horizons (depending on the rock) from the periphery to the roof of the super salt dome.

6. The porosity of potential reservoir rocks of tributary zones is higher than within remote zones. Porosity decreases in areas of maximum deposition of layers of rocks that are least exposed to changes in shape during halokinesis (fig.3).

According to the described features, we propose to introduce a classification of tributary zones:

I - zone RR (relict rocks) - rocks that had / have the minimal influence of the halokinesis process, have a smooth, monoclinic occurrence, the lowest indicators of reservoir properties, primary rock heights (formed during diagenesis and catagenesis of rocks without the influence of tectonics). The area is characterized by the absence of deposits or is an aquifer. 
II - zone MAU (multi-storey anticline ups and downthrows), arising over the salt body as a result of its vertical movement. Reservoir rocks are maintained over the area, partially dislocated, have the original RP. The thickness and shape of the layers are slightly changed, can be reduced over the stock as a result of partial compaction (compression). The zone is often gas-bearing (aquifer) in apical uplifts tectonic-shielded by downthrow dislocations of significant amplitude, anticlinal uplifts over the salt structure.

III - TZ (tributary zone) and CRA (over the stock area, or caprock area) - the most changed zone of rocks, which contains a large number of separated blocks, shifts, thrusts, raised layers, loosened and fractured reservoir rocks. The zone is oil and gas saturated.

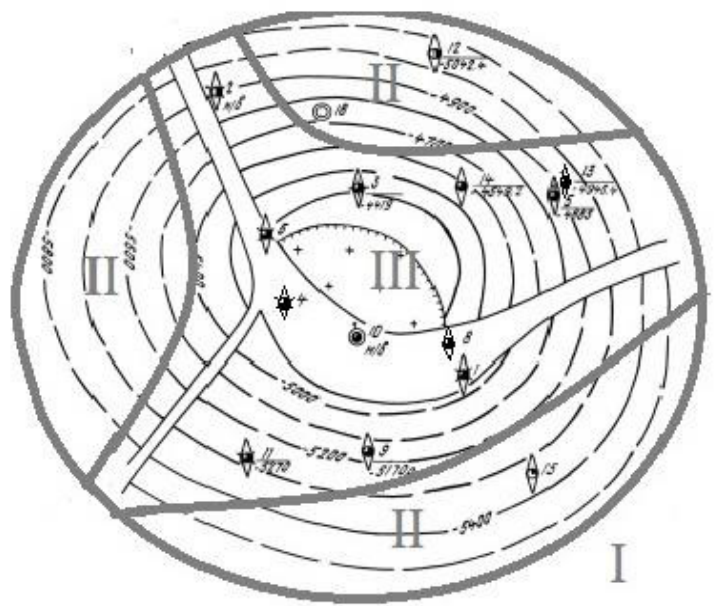

Fig. 4. Division of tributary zones according to classification and prospects of oil and gas potential: I - zone RR (relict rocks); II - zone MAU (multi-story anticline ups and downthrows); III - TZ (tributary zone) and CRA (over the stock area, or cap rock area)

The selected areas of perspective structure coincide with the drilling materials and confirm the fact that the process of halokinesis directly affects the change in the properties of reservoir rocks and the formation of hydrocarbon traps.

\section{Conclusions}

After analyzing the geological structure of DDB as a region with active halokinesis, as well as the structure of the Sakhalin field there was performed: 
- a division of tributary zones according to the features of geological, tectonic structure, forms of reservoir rocks, and their RP;

Such features of the geological structure are due to the manifestation of halokinesis structure-forming oscillatory movements in different periods of sedimentation with the inheritance of forms of structural surfaces, differing in their complexity and lithofacial type of section, type of traps, and the number and size of industrial hydrocarbon accumulations.

- the main differences in the characteristics of the reservoir rocks of the halokinesis zones are highlighted, according to which the classification of tributary zones is created;

- the model of the field corresponding to the spatial arrangement of hydrocarbon pay zones is created, based on repeated complex field and thematic seismic researches and data of prospecting and exploratory and production drilling.

It is confirmed by geological, productive profile sections and structural reference maps and can be used to perform further directions of oil and gas exploration work and rational choice of methods for studying new or additional exploration of partially discovered deposits associated with salt structures.

\section{Bibliography}

1. Vasylenko O.L. (2016) Fliuidodynamichna model pokladiv vuhlevodniv u soliano-zdvyhovykh strukturakh Dniprovsko-Donetskoi zapadyny. Visnyk Kharkivskoho natsionalnoho universytetu imeni V. N. Karazina, 23-27. http://nbuv.gov.ua/UJRN/VKhG_2016_45_5

2. Zyuzkevich M., Pavlenko P. (2003). Heolohiia, raionuvannia ta vyznachennia reitynhu perspektyvnosti heolohichnykh zon i naftohazonosnosti kompleksiv pivdenno-skhidnoi chastyny Dniprovsko-Donetskoi zapadyny. UkrNDIhaz, 46-54

3. Instruktsiia iz zastosuvannia klasyfikatsii zapasiv i resursiv korysnykh kopalyn derzhavnoho fondu nadr do heoloho-ekonomichnoho vyvchennia resursiv perspektyvnykh dilianok ta zapasiv rodovyshch nafty i hazu. DKZ (1998) https://zakon.rada.gov.ua/laws/show/z0475-98\#Text

4. Lukienko O.I. (2008) Strukturna heolohiia. TOV «KNT», 234-235.

5. Lubkov M.V. (2011) Modeliuvannia suchasnykh rukhiv lokalnykh struktur Dniprovsko-Donetskoi zapadyny. Heoiformatyka,(3), 54-60.

6. Solodkyi V.M., Bulishchenko O.M. (2009) Proekt poshukovorozviduvalnykh robit na naftu i haz u vizeiskykh vidkladakh Sakhalinskoho rodovyshcha vuhlevodniv. DP «Poltava RHP», 224 
7. Solodkyi V.M., Koliada M.I. (2009) Detalna heoloho-ekonomichna otsinka Sakhalinskoho naftohazokondensatnoho rodovyshcha Kharkivskoi oblasti Ukrainy. DP «Poltava RHP», (1), 31

8. Ustenko E.V., Petrunyak V.D., Vyzhva S.A. (2014). Suchasni pohliady na teoriiu vuhlevodnevykh system. KNU im. Tarasa Shevchenka, 59-57.

9. Fedyshyn V.O. (2003) Naukovi zasady otsiniuvannia nyzkoporystykh kolektoriv vuhlevodnevoho hazu. Lviv.

10. Jones F., Davison Ian. Seismic imaging in and around salt bodies. SEG Technical Program Expanded Abstracts 2014. https://doi.org/10.1190/segam20140047.1https://www.britannica.com/science/diapir. .

https://doi.org/10.31713/m1123

\section{EXPERIENCE IN IMPLEMENTING THE METHOD FOR DETERMINING THE INTEGRATED RISK ASSESSMENT OF ENGINEERING AND GEOLOGICAL PROCESSES FOR THE TERRITORY OF THE VOLYN-PODILSKY PLATE}

Koshliakov O. Ye.

Doctor of Geological Sciences, Professor,

Head of the Department of Hydrogeology and Engineering Geology, Institute of Geology, Taras Shevchenko National University of Kyiv

Kyiv, Ukraine

\section{Dyniak O.V.}

Candidate of Geological Sciences, Associate Professor of the Department of Hydrogeology and Engineering Geology, Institute of Geology, Taras Shevchenko National University of Kyiv Kyiv, Ukraine

\section{Koshliakova I.Ye.}

Engineer of the Department of Hydrogeology and Engineering Geology Institute of Geology, Taras Shevchenko National University of Kyiv, Kyiv, Ukraine

\section{Summary}

The condition of infrastructure facilities is directly dependent on the engineering and geological conditions of their location. Natural transformations are usually rather slow and are often determined only by consequences. The rate of destruction under the influence of man-made factors significantly exceeds the rate of natural development of the geological object. The main purpose of allocating engineering- 